Volume 13

\title{
Raphaël Lemkin's Derivation of Genocide from His Analysis of Nazi-Occupied Europe
}

\author{
Raffael Scheck \\ Colby College
}

Follow this and additional works at: https://digitalcommons.usf.edu/gsp

\section{Recommended Citation}

Scheck, Raffael (2019) "Raphaël Lemkin's Derivation of Genocide from His Analysis of Nazi-Occupied Europe," Genocide Studies and Prevention: An International Journal: Vol. 13: Iss. 1: 113-129.

DOI:

https://doi.org/10.5038/1911-9933.13.1.1584

Available at: https://digitalcommons.usf.edu/gsp/vol13/iss1/12

This Articles is brought to you for free and open access by the Open Access Journals at Digital Commons @ University of South Florida. It has been accepted for inclusion in Genocide Studies and Prevention: An International Journal by an authorized editor of Digital Commons @ University of South Florida. For more information, please contact digitalcommons@usf.edu. 


\section{Raphaël Lemkin's Derivation of Genocide from His Analysis of Nazi-Occupied Europe}

\section{Acknowledgements}

I thank Hilary Earl, Doris Bergen, Douglas Irvin-Erickson, Benjamin Lieberman, and the journal's two anonymous reviewers for comments and constructive criticism of an earlier version of this article. I also thank my son Anselm Scheck for helping me search for Lemkin's memo to President Roosevelt. I am especially grateful for the Audrey Wade Hittinger Katz and Sheldon Toby Katz endowed chair, which allowed me to do the archival research for this project. 


\title{
Raphaël Lemkin's Derivation of Genocide from His Analysis of Nazi-Occupied Europe
}

\author{
Raffael Scheck \\ Colby College \\ Waterville, Maine, USA
}

Popular understanding associates genocide with mass murder and connects it to the Holocaust, specifically the mass murder of Jews during the Second World War. As Martin Shaw states: "Just as Nazi anti-Jewish policy has been over-interpreted in terms of its final, exterminatory, phase, so genocide generally has been narrowed to extermination." ${ }^{11}$ Lemkin, however, defined genocide much more broadly. In Axis Rule in Occupied Europe, he argued that the Nazi occupation destroyed practically all subjected national or ethnic groups by attacking their culture, impoverishing them, and lowering their birthrate, with physical destruction being only one possible course of action. The mass murder of the Jews plays a surprisingly small role in Axis Rule. Lemkin did mention violence against Jews, specifically in Poland, and he provided bits of information throughout the book indicating that he was aware of the murderous Nazi policies against Jews, but he devoted little analysis to the Europe-wide deportation and killing program. ${ }^{2}$ The breadth and complexity of Lemkin's definition has confused historians and international lawyers and provoked the criticism that it is either too broad or too narrow. ${ }^{3}$

Recent research has helped to clarify the sources of Lemkin's thinking and the development of the genocide concept. A new biography by Douglas Irvin-Erickson traces the influence of the national cultural autonomy thinking of Austrian Marxist thinkers Otto Bauer and Karl Renner on Lemkin and shows that Lemkin's concept of the nation as a "community of character" and "family of mind" was more flexible than had been assumed. ${ }^{4}$ Martin Shaw provides a cogent explanation for the confusion regarding the definition of genocide, showing that Lemkin's original broader definition experienced a severe narrowing in the United Nations Genocide Convention (1948), which prompted many well-meaning but often confusing efforts by scholars to remedy the shortcomings of this definition. ${ }^{5}$ Anton Weiss-Wendt highlights the Soviet Union's role in narrowing the definition of genocide during the negotiations, while also giving due attention to the motives of other states such as a United States still practicing segregation and a Britain still committed to its colonial empire. ${ }^{6}$ In a double biography of Lemkin and Jan Karski, the Polish resister who testified to western governments about the mass murder of the Jews, French historian Annette Becker stresses Lemkin's role in alerting an incredulous western public to Nazi atrocities,

\footnotetext{
${ }^{1}$ Martin Shaw, What is Genocide? 2nd ed. (Cambridge, UK: Polity Press, 2015), 64. See also Jens Meierhenrich, "Introduction: The Study and History of Genocide," in Genocide: A Reader, ed. Jens Meierhenrich (Oxford and New York: Oxford University Press, 2014), 7 and 14-15.

${ }^{2}$ Raphaël Lemkin, Axis Rule in Occupied Europe. Laws of Occupation, Analysis of Government, Proposals for Redress (Washington, DC: Carnegie Endowment for International Peace, 1944), 21-22, 75-78, and 88-89.

${ }^{3}$ For good discussions of this confusion, see Eric D. Weitz, A Century of Genocide: Utopias of Race and Nation (Princeton and Oxford: Princeton University Press, 2003), 8-9; Shaw, What is Genocide?, vii and 53-65; Dan Stone, "Raphaël Lemkin on the Holocaust," in The Origins of Genocide: Raphaël Lemkin as a Historian of Mass Violence, ed. Dominik J. Schaller and Jürgen Zimmerer (London and New York: Routledge, 2009), 96; A. Dirk Moses, "Raphaël Lemkin, Culture, and the Concept of Genocide," in The Oxford Handbook of Genocide Studies, ed. Donald Bloxham and A. Dirk Moses (Oxford: Oxford University Press, 2010), 20-21 and 32-36; William Schabas, Genocide in International Law: The Crime of Crimes (Cambridge, UK and New York: Cambridge University Press, 2000), 25. But Schabas later says (wrongly in my opinion) that for Lemkin, "genocide was above all meant to describe the destruction of the Jews." (113). Schabas does emphasize the broad range of Lemkin's definition in his introduction to the new edition of Axis Rule, however: William Schabas, "Introduction to the Second Edition by The Lawbook Exchange, Ltd.," in Axis Rule in Occupied Europe. Laws of Occupation, Analysis of Government, Proposals for Redress, ed. Raphaël Lemkin (Clark, NJ: The Lawbook Exchange Ltd., 2014), x and xiv. Similarly: Samantha Powers, "Introduction to the First Edition," in Axis Rule in Occupied Europe. Laws of Occupation, Analysis of Government, Proposals for Redress, ed. Raphaël Lemkin (Clark, NJ: The Lawbook Exchange Ltd., 2014), xx-xxi.

${ }^{4}$ Douglas Irvin-Erickson, Raphaël Lemkin and the Concept of Genocide (Philadelphia: University of Pennsylvania Press, 2017), 5 and 61-66.

${ }^{5}$ Shaw, What is Genocide?, viii, 2-5, 8, and 13.

${ }^{6}$ Anton Weiss-Wendt, The Soviet Union and the Gutting of the UN Genocide Convention (Madison: The University of Wisconsin Press, 2017), 7.
}

Raffael Scheck. "Raphael Lemkin's Derivation of Genocide from His Analysis of Nazi-Occupied Europe" Genocide Studies and Prevention 13, 1 (2019): 113-129. @2019 Genocide Studies and Prevention. 
trying to overcome defensive reactions formed in response to the excesses of anti-German atrocity propaganda from the Great War. ${ }^{7}$

This article takes a fresh look at the creation of the term genocide. My basic point is that we need to keep in mind that Lemkin derived the concept from an analysis of a wide variety of Axis, especially German, occupation regimes. ${ }^{8}$ I argue that the development of the concept (probably between December 1942 and November 1943) was shaped by three factors. First, Lemkin shared a peculiar understanding of the Nazi regime's motives in the Second World War, namely the idea that Hitler, by waging a war on foreign peoples rather than states, was cynically calculating that even a militarily defeated Germany would dominate an impoverished and decimated Europe after the war. German aggression was therefore for Lemkin not simply a war of conquest but more precisely an attempt to carry out a demographic revolution for which a German military victory was not absolutely necessary. ${ }^{9}$ Second, Lemkin's thinking was influenced by the U.S. government agency for which he worked at the time, the Board of Economic Warfare (BEW), which was later integrated into the Foreign Economic Administration (FEA). This agency offered him great insights into the economic exploitation of occupied areas with an eye to future restitution efforts, but it did not focus on German atrocities. Third, Lemkin always remained focused on law, not policy. Resting his case on legal documents offered two advantages to him: it proved to a doubtful American public that Nazi cruelty and injustices were not war propaganda, and it provided the basis for the section of the book concerned with "Proposals for Redress," the last part of the subtitle. By identifying German violations of the international law on occupations, mostly of the Hague Regulations (1907), Lemkin could make a case for the introduction of new international laws on genocide and on military occupations. On the other hand, the book's legal focus obscured the most atrocious Nazi crimes, which rarely proceeded according to published laws and decrees.

All of these factors colluded to create a very broad definition of genocide that contributed great insights on the exploitation and repression of Axis-occupied Europe but did not highlight the most atrocious Nazi policies and left confusion as to the general application of the new concept. When Lemkin distributed the book to U.N. delegations in his campaign for an international law banning genocide, some countries, for example the Soviet Union, therefore found it easy to interpret the U.N. Genocide Convention primarily as a law against a future Nazi movement. ${ }^{10}$

\section{The Concept of Genocide in Axis Rule}

It is important to keep in mind that the three parts of the book came into being in reverse chronological order. The oldest and by far largest component is Part III, which consists of translated laws and decrees from Axis-occupied Europe. Lemkin had begun to collect these documents during his appointment at the University of Stockholm, where he had found refuge in early 1940 following the German and Soviet conquest of Poland. When Lemkin received an invitation to teach at Duke University and a visa to the United States, he packed this collection into a suitcase and brought it with him in April 1941. ${ }^{11}$ His host at Duke, Professor Malcolm McDermott, took

\footnotetext{
${ }^{7}$ Annette Becker, Messagers du désastre. Raphaël Lemkin, Jan Karski et les génocides (Paris: Fayard, 2018), esp. 98-109. One would have to clarify, however, that Lemkin was a "messenger of disaster" in the sense that the disaster he communicated was the Axis occupation of Europe, not specifically the Holocaust. In his address to the North Carolina Bar Association in May 1942, for example, he focused on German manipulations of the courts in Poland and some other occupied countries. He did not mention the Jews at all: Raphaël Lemkin, "Law and Lawyers in the European Subjugated Countries," in Proceedings of the Forty-Fourth Annual Session of the North Carolina Bar Association, ed. Allston Stubbs, 107-116 (Durham: Christian Printing, 1942).

${ }^{8}$ Lemkin referred to Axis policies and duly analyzed Italian, Hungarian, Croatian, Slovak, Bulgarian, Romanian, and Vichy French laws and decrees, but he believed that these policies followed the "German pattern." Lemkin, Axis Rule, 3-4 and, for an example, 188.

${ }^{9}$ Most scholars have paid little attention to this fact. Irvin-Erickson mentions it but discusses it mostly in the context of Lemkin's hopes to stop Nazi genocide during the war: Douglas Irvin-Erickson, Raphaël Lemkin and the Concept of Genocide (Philadelphia: University of Pennsylvania Press, 2017), 136. See also William Korey, An Epitaph for Raphaël Lemkin (New York: Jacob Blaustein Institute for the Advancement Human Rights of the American Jewish Committee, 2001), 16-17.

${ }^{10}$ Irvin-Erickson, Lemkin, 167. Weiss-Wendt, The Soviet Union, 7 and 111.
} 
Lemkin to Washington D.C. and introduced him to John Vance, the law librarian of the Library of Congress, who helped him find more Axis orders and decrees. ${ }^{12}$ Through Vance, Lemkin also met Colonel Archibald King, who worked in the military government section of the War Department. King attended some of Lemkin's classes at Duke and expressed interest in Lemkin's document collection. ${ }^{13}$ Lemkin therefore translated his documents into English and used them as a looseleaf collection entitled "Military Government in Europe" in his courses at Duke and also for a course at the War Department's School of Military Government in Charlottesville, Virginia, in the summer of 1942. The collection, which is organized alphabetically by occupied country, includes no commentary and does not use the term genocide. Lemkin obviously understood it as a work in progress; the pages were numbered in a way that allowed for additional laws to be inserted. The collection includes some laws reprinted in Part III of Axis Rule, but it is thinner than the material in Part III. ${ }^{14}$

Thanks to his document collection, Lemkin came to the attention of U.S. Government officials. In June 1942, he was invited to work for the Board of Economic Warfare. ${ }^{15}$ While working at the BEW, Lemkin completed an expanded version of his collection under the title "Key Laws, Decrees, and Regulations Issued by the Axis in Europe" in December 1942. This version included brief introductions to the occupation regimes of specific countries that resemble the sections of Part II in Axis Rule, where Lemkin surveys Axis laws and decrees in each occupied country. In the preface to this collection, Lemkin makes a distinction between countries where Germany tolerates some form of collaborating regime or administration (western and northern Europe), those countries where total subjugation is the aim (mostly Poland, the Soviet Union, and parts of Yugoslavia), and territories incorporated (illegally annexed) into the Reich, such as Alsace-Lorraine, Luxemburg, and western Poland. This collection contains more laws and decrees published in Part III of Axis Rule and outlines of the analysis presented in Part II, but it still omits some occupied countries and does not use the term genocide. Lemkin presented this manuscript to George Finch, the director of the Carnegie Endowment for International Peace, who agreed to publish it. ${ }^{16}$ Finch therefore committed himself to publishing foremost an analysis and documentation of Axis occupation regimes, which may explain why he did not mention the term genocide in his foreword to Axis Rule, dated August 18, $1944 .{ }^{17}$

In the following eleven months, Lemkin finalized the manuscript for Axis Rule. He signed the preface on November 15, 1943, and it appears that the manuscript was complete by that date (although Lemkin inserted some new information later on). Yet, disputes between Lemkin and his publisher delayed the publication of the book, so that it only came out a year later. ${ }^{18}$ To the manuscript he had compiled in December 1942, Lemkin added sections on Greece (he received detailed information on Greece only in the course of 1943 while working for the BEW), and he expanded the section on Yugoslavia, which had previously focused only on Serbia. Given that Greece and Yugoslavia were also subjected to non-German occupation regimes, Lemkin elaborated on Italian, Bulgarian, and Hungarian occupation practices, and he presented new material on the Romanian occupation of Soviet territory. He also expanded the legal discussion of the occupation

\footnotetext{
${ }^{11}$ John Cooper, Raphaël Lemkin and the Struggle for the Genocide Convention (Basingstoke and New York: Palgrave Macmillan, 2015 [first 2008]), 34-35 and 46; Raphaël Lemkin, Totally Unofficial: The Autobiography of Raphaël Lemkin (New Haven and London: Yale University Press, 2013), 76-77; Philippe Sands, East West Street: On the Origins of "Genocide" and "Crimes Against Humanity" (New York: Alfred A. Knopf, 2016), 168-173. The collection now rests in the Raphaël Lemkin Papers, series I, boxes 1-3, in the Rare Books and Manuscript Library at Columbia University in New York City.

${ }^{12}$ Lemkin, Totally Unofficial, 106-108.

${ }^{13}$ Ibid., 108-109.

${ }^{14}$ Raphaël Lemkin, “Military Government in Europe,” (University of North Carolina Law Library, 1942).

${ }^{15}$ Lemkin, Totally Unofficial, 112.

${ }^{16}$ Lemkin, Totally Unofficial, 116. The loose-leaf collection is available in a few libraries (including the law library of the University of North Carolina) and in several record groups at the National Archives.

${ }^{17}$ George A. Finch, Foreword to Lemkin, Axis Rule, vii-viii.

${ }^{18}$ Irvin-Erickson, Lemkin, 81. The latest reference I found in the book refers to the first trials against German war criminals in the Soviet Union in December 1943: Lemkin, Axis Rule, 237.
} 
regimes in Part II. The most important addition was Part I, the shortest section of the book. It focuses on German administration techniques and is organized by subject, not country. It synthesizes the occupation practices described in Part II and documented in Part III, although it also introduces some generic remarks about law in Nazi Germany and about measures applying to all occupied countries. The chapters of Part I cover topics such as administration, police, law, courts, property, finance, labor, and the legal status of the Jews. They draw from information Lemkin had compiled for the BEW. ${ }^{19}$ Chapter 9 of Part I works like a synthesis of the previous chapters and is entitled "Genocide;" it surveys eight different techniques of genocide and articulates recommendations for the future. This chapter comprises only 16 pages, but it is the most widely read - together with Lemkin's Preface (7 pages), which introduces the term genocide.

The genocide chapter highlights Lemkin's inclusive understanding of the term because it subsumes all of the acts surveyed in the preceding chapters under eight genocidal policies, ranging from political to social, cultural, economic, biological, physical, religious, and moral. Lemkin also frequently uses the terms "genocide" or "genocidal" in the second and third parts of the book, but only very rarely in connection to mass killings. For example, a section entitled "Genocide and Resistance" in Part II describes German censorship and anti-Czech cultural policies in the Protectorate of Bohemia and Moravia. The chapter on Greece states, "a real genocide policy was applied to the Greeks in the Aegean region" by the Bulgarian occupiers and explains: "Greek churches and schools were closed and the Bulgarian language was made the official language. These measures aimed at changes in the composition of the population in accordance with the German pattern." ${ }^{20}$ The sections on Norway highlight laws giving German citizenship to the illegitimate children of German soldiers and Norwegian women. France is the focus of economic exploitation and Germanization policies in Alsace-Lorraine. Lemkin cites the anti-Jewish laws of the Vichy government and laws of the German Military Commander in France aiming to register and expropriate Jews.

In Part III, the collection of laws, Lemkin devotes four pages to a sub-chapter entitled "Genocide Legislation" in Luxemburg, listing various Germanization laws, ranging from compulsory name changes to the teaching of German in schools and decrees favoring the Lutheran church. By comparison, he devotes only three pages to genocide legislation in Poland (dealing only with certain privileges for ethnic Germans in the General Government) and none on the occupied Soviet territories. ${ }^{21}$ Lemkin often equates genocide with an assault on minority culture, as for example in the Croatian law banning the Cyrillic alphabet in Croatian-occupied Bosnia, the Magyarization policies in the Hungarian-occupied territories of Yugoslavia, and the German language policies in Alsace-Lorraine, Luxemburg, and the incorporated parts of Poland. ${ }^{22}$ Furthermore, he highlights examples of forced population movements through economic pressure or deportation, as for example in the parts of Greece incorporated by Bulgaria and, again, the German-annexed parts of Poland. ${ }^{23}$

Lemkin includes all of these policies on the spectrum of genocide. His definition incorporates a range of policies from relatively harmless measures such as the inclusion of foreigners with German heritage into the German racial community to the physical destruction of unwanted populations, particularly Jews. Within this spectrum, genocide applies to the repression of the culture and language of occupied peoples and the imposition of the occupier's culture and language

\footnotetext{
${ }^{19}$ See, in particular, Raphäel Lemkin, "Civil Affairs Guides," on the Nazi party, the courts, the police, and the SS, National Archives and Records Administration (hereafter NARA), RG 153 Judge Advocate General, Office of Economic Warfare, Boxes 2 and 5, L-99.

${ }^{20}$ Lemkin, Axis Rule, 188.

${ }^{21}$ Ibid., 440-443, 552-555.

${ }^{22}$ Mark Mazower argues that Lemkin remained wedded to the old principle of minority rights embedded in the Paris peace treaties of 1919 that meant foremost to protect the language and culture of minorities in the new multi-ethnic states of eastern central Europe. Mazower argues that Lemkin wanted to create an improved version of these treaties in the form of the UN Genocide Convention. The cited passages confirm this impression: Mark Mazower, No Enchanted Palace: The End of Empire and the Ideological Origins of the United Nations (Princeton: Princeton University Press, 2009), 129-130.

${ }^{23}$ Lemkin, Axis Rule, 172-173, 188, 223-225, 245, 259-60, 262-264.
} 
(a phenomenon later called "cultural genocide"24); economic exploitation; forced labor; and the deportation of native populations and the encouragement of settlement in the newly occupied areas by members of the dominant nation (something we would call "ethnic cleansing" today and that Lemkin sometimes called "colonization" in Axis Rule). Lemkin advocated a holistic view of genocide even though he soon recognized that his eight categories were too complicated and partly redundant, so that he reduced them to only three: physical, cultural, and biological. ${ }^{25}$ There is another factor, however, that holds together the eight genocidal policies: Lemkin's view of Nazi goals in World War II.

\section{Genocide as Demographic Revolution Regardless of Military Outcome}

For Lemkin, all genocidal policies he outlined emanated from an overarching German intention to massively change the demographic balance of Europe. He argued that all these policies were part of a cynical scheme by the Nazi regime to ensure that Germany would win the war demographically even if it lost militarily. As he writes in the preface to Axis Rule:

The picture of coordinated German techniques of occupation must lead to the conclusion that the German occupant has embarked upon a gigantic scheme to change, in favor of Germany, the balance of biological forces between it and the captive nations for many years to come. The objective of this scheme is to destroy or to cripple the subjugated peoples in their development so that, even in the case of Germany's military defeat, it will be in a position to deal with other European nations from the vantage point of numerical, physical, and economic superiority. Despite the bombings of Germany, this German superiority will be fully evident after hostilities have ceased and for many years to follow, when, due to the present disastrous state of nourishment and health in the occupied countries, we shall see in such countries a stunted post-war generation, survivors of the ill-fed children of these war years. ${ }^{26}$

Lemkin returns to the same idea in the chapter on genocide, claiming that the Nazi scheme was devised before the start of the war: "Thus the German people in the post-war period will be in a position to deal with other European peoples from the vantage point of biological superiority. [...] In this respect genocide is a new technique of occupation aimed at winning the peace even though the war itself is lost." ${ }^{27}$ One may assume that the actual course of the war, especially the dogged and very costly resistance of the German armed forces in the last months of the conflict, induced Lemkin to revise this idea of a demographic revolution as the ultimate Nazi war aim regardless of the military outcome. Yet, he repeated this notion in various papers and articles after the war. ${ }^{28}$

The origins of this notion are hard to trace. If one can believe Lemkin's autobiography, he mentioned it already in the spring of 1941 to Colonel Archibald King. After a discussion of German violations of the Hague Regulations, Lemkin explained:

\footnotetext{
${ }^{24}$ Although "cultural genocide" corresponded quite well to Lemkin's definition of cultural, moral, and religious genocide, he initially opposed using the term because he saw it as a plot of his enemies to squeeze out the destruction of cultures from the planned U.N. Genocide Convention and to reduce genocide to mass killing. That is more or less what ultimately happened, much to the chagrin of Lemkin: Irvin-Erickson, Lemkin, 176 and 182-189.

${ }^{25}$ Thomas M. Butcher, “A 'Synchronized Attack': On Raphaël Lemkin's Holistic Conception of Genocide," Journal of Genocide Research 15, no. 3 (2013).

${ }^{26}$ Lemkin, Axis Rule, xi.

${ }^{27}$ Ibid., 81.

${ }^{28}$ Raphaël Lemkin, "The Crime of Genocide" in Bulletin de la Commission internationale et pénitentiaire, vol. XII, 34-43, n.d., with draft found in Raphaël Lemkin Papers, P-154, American Jewish Historical Society (hereafter AJHS), Box 5, Folder 3. See also: Raphaël Lemkin, "Genocide. A New International Crime. Punishment and Prevention," Revue internationale de droit pénal, (Paris, 1946), 360-370, with draft found in Raphaël Lemkin Papers, P-154, AJHS, Box 13, Folder 2, 363-364; Raphaël Lemkin, "Genocide as a Crime Under International Law," The American Journal of International Law, 41, no. 1, January 1947, 147, with draft found in Raphaël Lemkin Papers, P-154, AJHS, Box 5, Folder 3.
} 
Hitler intends to change the whole population structure in Europe for a thousand years - which means virtually forever. Certain races or nations will disappear completely or be crippled indefinitely. Even in the case of German defeat, the Germans have it planned that these remaining nations will have to lean on Germany to stay alive. The Germans are trying to defeat and destroy not governments, but peoples. ${ }^{29}$

The reference to Hitler's intention is based on a passage in the book Gespräche mit Hitler by former Danzig Senate President Hermann Rauschning, published in Zürich in 1940. In Axis Rule, Lemkin cites the English translation that appeared in New York the same year. The relevant passage reflects a statement by Hitler: "We shall have to develop a technique of depopulation. If you ask me what I mean by depopulation, I mean the removal of entire racial units." Further down, Hitler allegedly explains that he would seek to decrease the high birth rate of Slavic populations through unbloody methods such as prolonged separation of men and women. Lemkin did not know this, but Rauschning is now considered a dubious source who exaggerated his closeness to Hitler and reported many expressions by Hitler as verbatim that he likely did not hear in personal conversation with him. ${ }^{30}$

The notion that Nazi occupation meant a deadly chokehold on European countries, and that Nazi Germany was using occupations to carry out a demographic revolution, was present in American public discourse during the war. For example, a New York Times article from March 10, 1942, entitled "Death under the New Order," spells out some ideas that shape Axis Rule. Focusing on the civilian deaths resulting from the war, the article draws attention to the demographic loss created by the separation of men and women from occupied countries, implying what Lemkin would later call biological and economic genocide: "Hitler is just as surely murdering the French when he keeps more than 1,500,000 war prisoners away from their families as he is when he shoots hostages or takes milk and eggs away from children." The article further observes: "'Life-room' [Lebensraum] for these Nazi gorillas means death-room for other people. Murder by starvation, by overwork, by deprivation of medical care, by systematic abuse would make a Nazi peace as destructive as a Nazi war - even more destructive, because the Nazis could then proceed without interruption." After alluding to similar policies by Japan, the article concludes: "The Axis system may be precisely defined as a system of death." ${ }^{31}$ The article also reflects the widespread notion in America that Jews were just one of many persecuted groups, an opinion that failed to grasp the viciousness and particularity of Nazi policies against the Jews. ${ }^{32}$

The idea that Nazi Germany would win the peace through a demographic victory regardless of the military outcome rests on two related implications that Lemkin never spelled out. First, it only made sense if German losses remained low in comparison to the losses inflicted by Germany on its enemies and on civilians in the occupied countries. Second, the defeat of Germany and the transition to peace would have to come in a relatively smooth manner that would not lead to the destruction of the German nation by the victorious Allies. In Axis Rule and in other wartime documents, Lemkin cites no numbers of German deaths and does not reveal how he expects the war to end. It was known that German losses had been relatively low before the attack on the Soviet Union, but they massively increased thereafter..$^{33}$ In the American press, exaggerated Soviet figures

\footnotetext{
${ }^{29}$ Lemkin, Totally Unofficial, 109. He wrote a very similar passage in his handwritten draft for the autobiography: New York Public Library, Manuscripts and Archives Division, Microfilm, Reel 2, Notebooks, 24a and 25.

${ }^{30}$ Hermann Rauschning, The Voice of Destruction (New York: Putnam, 1940), 138. Lemkin, Axis Rule, 81. Ian Kershaw, echoing earlier work by Theodor Schieder, warns against using Rauschning's work as a verbatim source of what Hitler actually said but admits that "there is nothing in it which is not consonant with what is otherwise known of Hitler's character and opinions." Ian Kershaw, The Nazi Dictatorship: Problems and Perspectives of Interpretation, 5th ed. (London: Bloomsbury, 2015), 182.

31 "Death under the New Order," New York Times (1923-Current file), March 10, 1942,18. My student Huan Bui brought this article to my attention.

${ }^{32}$ Richard Breitman et al., U.S. Intelligence and the Nazis (New York: Cambridge University Press, 2005), 11. (I owe this reference to my student Jonah Carter.) See also Laurel Leff, Buried by the Times: The Holocaust and America's Most Important Newspaper (New York: Cambridge University Press, 2005), 3.
} 
of German deaths stood next to excessively low German estimates. ${ }^{34}$ Lemkin clearly did not foresee the extremely bloody last phase of the war, nor did he anticipate the large wave of retaliatory violence against German civilians and POWs in Soviet hands before and after the German surrender, which increased the German death toll. ${ }^{35}$ Even though more than half of the German losses occurred after Lemkin had completed the book manuscript (from mid-July 1944 to May 1945), it is surprising that he did not expect a bloodier end to the war. Lemkin professed to have read Mein Kampf and therefore knew about the fanaticism and Social Darwinism inherent in Hitler's ideology, although his reading of Rauschning suggests that he might also have been influenced by a more nihilistic and opportunistic view of Hitler. As Dan Stone explains, Lemkin understood Hitler's fanaticism but at the same time tended to see Hitler's ideology, like Rauschning, as a way to a means, the forging of national unity, not as an end in itself. ${ }^{36}$

Many German policies, in particular the Germanization measures, would certainly not have survived a German defeat. The forced resettlement policies could be (and were) turned back, and even during the war it proved difficult to motivate ethnic Germans to settle in the areas of Poland and Slovenia they were supposed to colonize. ${ }^{37}$ Yet, the notion that Nazi Germany was waging a demographic war regardless of the outcome of the military conflict explains why policies such as the granting of German citizenship to Norwegian babies or the ridiculous Germanization of names in Luxemburg occupy so much room in Axis Rule.

\section{Lemkin's Work in the Board of Economic Warfare}

A second factor influencing the development of the concept "genocide" was Lemkin's every-day work on the BEW. Nobody has analyzed yet what exactly Lemkin did inside the BEW and how his work may have influenced his understanding of Nazi occupation policies and genocide. ${ }^{38}$ The BEW, formed in April 1942 out of the Economic Defense Board, focused on import and export controls, aiming to maximize the allocation of resources for the U.S. and its allies while trying to prevent the Axis powers from acquiring resources in neutral countries. The young Arthur Schlesinger Jr., later an eminent historian, considered applying for a position on the BEW, whose work he believed to be attractive and exciting: "People were rushing around doing things - imposing blockades, buying up scarce raw metals, blacklisting Axis-controlled firms, plotting to deny the enemy strategic materials." ${ }^{39}$ But other observers and historians have characterized the BEW as a toothless outgrowth of President Roosevelt's misguided desire to create new war agencies with overlapping competencies. ${ }^{40}$ For political scientist Donald G. Stevens, the BEW was largely an attempt by its

${ }^{33}$ Rüdiger Overmans, Deutsche militärische Verluste im Zweiten Weltkrieg, Beiträge zur Militärgeschichte (Munich: Oldenbourg, 1999), 2.

34 “Germany's Casualties: A 4,000,000 Estimate Viewed as at Odds With Nazi Capacity for New Offensives," New York Times, February 8, 1943, 4. The article compares the state of the German war effort in 1943 to 1918. This analogy reflected a widespread perception in Nazi-occupied Europe after the conclusion of the Battle of Stalingrad. It was encouraged by British propaganda: Peter Fritzsche, An Iron Wind: Europe under Hitler (New York: Basic Books, 2016), 155-156. See also Washington Post, February 20, 1943, and New York Times, February 24, 1943. Earlier, Soviet sources had estimated "Nazi" losses during the winter 1941-42 at 1.1 million, with 800,000 killed (New York Times, May 18, 1942).

${ }^{35}$ Richard Bessel, Germany 1945: From War to Peace (New York: Harper Collins, 2009); R.M. Douglas, Orderly and Humane: The Expulsion of the Germans after the Second World War (New Haven: Yale University Press, 2012); Stephen Fritz, Endkampf: Soldiers, Civilians, and the Death of the Third Reich (Lexington: University Press of Kentucky, 2004); Keith Lowe, Savage Continent: Europe in the Aftermath of World War II (New York: St. Martin's, 2012).

${ }^{36}$ Dan Stone, "Raphaël Lemkin on the Holocaust," Journal of Genocide Research 7, no. 4 (2005), 545. See also Hermann Rauschning, The Revolution of Nihilism. Warning to the West, trans. E.W. Dickes (New York: Alliance Book Corporation, 1939).

${ }^{37}$ Mark Mazower, Hitler's Empire: How the Nazis Ruled Europe (New York: Penguin, 2008), 79-81, 203-204.

${ }^{38}$ Tanya Elder called for such a research project, however: Tanya Elder, "What You See Before Your Eyes: Documenting Raphaël Lemkin's Life by Exploring His Archival Papers, 1900-1959," in The Origins of Genocide: Raphaël Lemkin as a Historian of Mass Violence, ed. Dominik J. Schaller and Jürgen Zimmerer (London and New York: Routledge, 2009).

${ }^{39}$ Arthur M. Jr. Schlesinger, A Life in the Twentieth Century. Innocent Beginnings, 1917-1950 (Boston and New York: Houghton Mifflin, 2000), 295.

${ }^{40}$ Daniel R. Ernst, "The Ideal and the Actual in the State: William Hurst at the Board of Economic Warfare," in Total War and the Law: The American Home Front in World War II, ed. Daniel R. Ernst and Victor Jew (Westport: Praeger, 2002), 
chairman, Vice President Henry A. Wallace, to create a stronger power base for the vice presidency. Embattled by competing agencies and conservative Congressmen who suspected Wallace of trying to project New Deal policies onto the global sphere, the BEW was dissolved in June 1943 by an executive order from Roosevelt. ${ }^{41}$ Its personnel and functions migrated to the Office of Economic Warfare, which was itself integrated into the Foreign Economic Administration (FEA) in September $1943 .{ }^{42}$

Given the institutional instability of the BEW and its successors, it is difficult to find Lemkin's traces in these agencies despite a remarkable continuity of personnel..$^{43}$ The archival documentation suggests that he occupied a rather low rung in the hierarchy of this agency. The BEW contained six principal offices, some of which were divided into so-called branches. The eleven branches were themselves sub-divided into divisions. Lemkin worked first in the British Empire division (until 9 December 1942) ${ }^{44}$ and then in the "Reoccupation Division" (sometimes listed as "Reoccupation and Reconstruction Division") of the "Blockade and Supply" branch, which itself belonged to the "Office of Economic Warfare Analysis." He did not head the "Reoccupation Division," nor was he present at the top-level meetings of the BEW. ${ }^{45}$ Lemkin was hired as a perdiem "chief consultant" with a pay of $\$ 18.05$ per day (approximately $\$ 285$ in 2018 value) not to exceed 180 days per year. ${ }^{46}$ In describing his work, a personnel manager at the BEW stated:

Dr. Lemkin is engaged in preparing an annotated collection of key laws (in translation) issued by the Axis in German-Occupied Europe. This collection... is essential for determination of laws to be cancelled or reviewed prior to Allied occupation. Dr. Lemkin, who is an outstanding international lawyer, is engaged in analysis of these laws and in recommending policy to be adopted with regard to them... His extensive knowledge of Europe and his very specialized knowledge of the problems of military government - he is a recognized authority on this subject - make him essential to the work of the Reoccupation and Reconstruction Division of the Board of Economic Warfare. ${ }^{47}$

155. For another critical evaluation, see Dean Acheson, Present at the Creation. My Years in the State Department (New York: Norton, 1969), 39-47. Also: Paul A. C. Koistinen, Arsenal of World War II: The Political Economy of American Warfare, 1940-1945, Modern War Studies (Lawrence, Kansas: University Press of Kansas, 2004), 8, 116, 267-268. Koistinen pays little attention to the Board of Economic Warfare (hereafter BEW) in his book because he claims that it did not achieve much.

${ }^{41}$ Donald G. Stevens, “Organizing for Economic Defense: Henry Wallace and the Board of Economic Warfare's Policy Initiatives, 1942," Presidential Studies Quarterly 26, no. 4 (1996); Henry A. Wallace, The Price of Vision: The Diary of Henry A. Wallace (Boston: Houghton Mifflin, 1973).

${ }^{42} \mathrm{H}$. Stephen Helton, Preliminary Inventory of the Records of the Foreign Economic Administration (Washington, DC: The National Archives, 1951), 58.

${ }^{43}$ Helton, Preliminary Inventory, 39. A complicating factor is that the National Archives integrated some of the BEW's papers into other collections, such as the War Department and the OSS files. A folder entitled "Dr. Raphaël Lemkin's Material" exists in the Records of the Office of the Judge Advocate General (Navy) RG 125, General Records, 19451949, Entry A1-13. NAID 16465283. It contains a memo by Lemkin from early 1946 in which he argues that the geopolitical ideas of Karl Haushofer formed the foundation of both Nazi and Japanese aggression and that Haushofer should therefore be tried in Tokyo. Although Lemkin's superiors liked the idea, nothing came of it because Haushofer committed suicide in March 1946. Aside from the memo, the folder includes materials on the Riom Trials in Vichy France (1942), some materials on Japanese suspected war criminals, and a Civil Affairs Guide to Germany - all without listing Lemkin as the author.

44 "Recommendation to the Personnel Officer," December 9, 1942, Raphaël Lemkin, personnel files of the BEW, National Personnel Records Center. Why Lemkin was assigned to the British Empire Division in the first months is totally unclear. He had no expertise on the British Empire and seems to have worked on his document collection and on guidebooks from the start.

${ }^{45}$ Helton, Preliminary Inventory, vi and 52.

46 "Recommendation to the Personnel Officer," December 9, 1942, and "Investigation A," November 17, 1942, Raphaël Lemkin, personnel files of the BEW, National Personnel Records Center. For conversion of 1940s dollars to present value, see Scott Derks, The Value of A Dollar: Prices and Incomes in the United States from 1860 to 2009 (Armenia: Grey House Publishers, 2009), xix

47 "Request for Occupational Deferment," late 1942/ early 1943, Raphaël Lemkin, personnel files of the BEW, National Personnel Records Center. The request mentions a guidebook on France that Lemkin had just completed. There is a guidebook on occupied France dated March 31, 1944, in the files (NARA, RG 153, Judge Advocate General, Office of Economic Warfare, Box 5 L-99,). However, the letter still refers to the BEW, indicating that it must have been written 
In the "Reoccupation Division," which was renamed "Economic Institutions Staff" in 1944, Lemkin worked on questions of government, administration, economics, and law in Nazi Europe, with special attention to the occupied countries. His boss, Allen R. Rosenberg, requested reports on special themes every Monday (by noon), and these reports likely provided the information for guidebooks on Nazi-occupied Europe that the "Reoccupation Division" produced and updated every couple of months. The guidebooks then were sent to the military and to other agencies interested in the occupied or liberated territories. ${ }^{48}$ The archives of the "Reoccupation Division" contain studies on specific occupied countries, the so-called "Civil Affairs Guides," as well as studies on generic aspects of the Axis-occupied areas. Most of the "Civil Affairs Guides" and thematic studies refer to laws and decrees that Lemkin had collected and that he published in Axis Rule. One guidebook, for example, analyzes the way in which the German police and the SS expanded their administrative power beyond the Reich and helped to control and exploit occupied Europe. This text mirrors the chapter on the German police and SS in Axis Rule. ${ }^{49}$ The guidebooks are all rigorously crafted and reflect great legal and economic expertise. Although they do not list an author, Lemkin's authorship is extremely likely because the note from the personnel manager cited above mentions that he was charged with producing informational manuals on occupied Europe and because the guidebooks clearly draw from his source material and reflect his interpretations of German policies without, however, using the term genocide..$^{50}$

The work of the Reoccupation Division had implications for other government services. As the Allied forces began to liberate occupied areas, the information on Nazi laws and exploitation mechanisms gathered by the Reoccupation Division became relevant for post-liberation administrations and for the restitution of robbed property, a major concern of the BEW/FEA and also of Axis Rule. ${ }^{51}$ The Reoccupation Division therefore cooperated with the Office of Strategic Services (OSS) and with the military agencies concerned with administering and reconstructing the former occupied territories..$^{52}$ Lemkin's work was also relevant for the agencies concerned with future war crimes trials because his documentation provided material for postwar trials and restitution arrangements. His collection of Axis laws and decrees from December 1942 wandered into the archives of the Judge Advocate General, the War Department, and the FEA. Lemkin produced a supplementary volume on Greece in June 1943, which he also integrated into Axis Rule. ${ }^{53}$

It was therefore not the case, as one of his biographers has suggested, that Lemkin turned to Axis Rule in the evenings after coming home from the office: Lemkin's daily work consisted precisely of the study of Nazi occupation policies. ${ }^{54}$ His role as counselor in the BEW focused on legal and economic matters and appealed to two areas in which Lemkin was already an internationally recognized expert before the war: constitutional law and currency exchange. Lemkin had participated in the drafting of the Polish penal law code in the 1920s, and he had written book-

before July 1943, and it mentions the Reoccupation and Reconstruction Division, which Lemkin had joined on December 9, 1942.

48 "Allen R. Rosenberg to Division and Section Heads," September 2, 1944, NARA, RG 169, Foreign Economic Administration, Entry 216, Box 1137.

${ }^{49}$ Lemkin, Axis Rule, 15-24. For the guidebook, see Raphäel Lemkin, “German Military Government Over Europe 19391943 Methods and Organization of Nazi Controls. German Military and Police Tribunals in Occupied Territories," October 25, 1943, NARA, Judge Advocate General Law Library, 1944-1949, Entry 135, Box 5.

50 "Request for Occupational Deferment," n.d., Raphaël Lemkin, personnel files of the BEW, National Personnel Records Center. A 1944 report of the FEA mentions these Civil Affairs Guides, created in conjunction with the OSS, as an important preoccupation of the Foreign Economic Administration, Report to Congress on Operations of the Foreign Economic Administration, September 25, 1944 (Washington, DC: United States Government Printing Office, 1944 ), 42.

${ }^{51}$ Lemkin, Axis Rule, xii-xiii. In his foreword to the book, George Finch also stresses these purposes: vii-viii.

${ }^{52}$ The guide books created by the "Reoccupation Division" show the OSS initially as a co-sponsoring agency and later as the sole responsible editor: NARA, RG 169, Foreign Economic Administration, Entry 216, Box 1137.

${ }^{53}$ The booklet on Greece reflects mostly laws from 1941. Lemkin writes that it comes so late because very little information on Greece had been available earlier. NARA, College Park, RG 165, Military Agency Records, Box 150.

${ }^{54}$ Richard Szawlowski, “Raphaël Lemkin's Life Journey: From Creative Legal Scholar and Well-to-do Lawyer in Warsaw until 1939 to Pinnacle of International Achievements during the 1940s in the United States, Ending Penniless Crusader in New York in the 1950s," in Rafal Lemkin: A Hero of Humankind, ed. Bienczyl-Missala. Agnieszka and Slawomir Debski (Warsaw: The Polish Institute of International Affairs, 2010), 43. 
length analyses on the legal system of Fascist Italy and of the Soviet Union. As a financial expert, he had published a book in French and one in Swedish on currency exchange before traveling to America. ${ }^{55}$ Clearly, this knowledge helped him for example to explain how German currency policies in occupied France were draining the local economy, a phenomenon he also characterized as genocide. ${ }^{56}$ But while Lemkin was analyzing the myriad ways in which German policies helped to exploit occupied territories and violated the Hague Regulations, his work at the BEW only rarely touched on the mass deportations of Jews and the fate of the deported after arrival.

What did Lemkin know about the Europe-wide deportation and mass murder of the Jews? In Axis Rule, he highlights the expropriation of Jews, which was more visible in decrees than the mass murder. ${ }^{57}$ Yet he clearly was aware of the Nazis' murderous policies. For example, he points out starvation rations in the Polish ghettos and occasional massacres, and he mentions a Gestapo chief who "organized the liquidation of the ghettos in Polish towns, with the physical annihilation of half a million inhabitants of the Warsaw ghetto." He mentions murder of Jews with the help of gas chambers, electrocution, and "death in the so-called death trains by the action of quick-lime." ${ }^{58} \mathrm{He}$ also refers to the deportation of Jews from France, Belgium, the Netherlands, and Norway to Poland, where they were treated in the same way as Polish Jews. In a footnote, he even acknowledges the escape of approximately one thousand Jews from Denmark to Sweden in August $1943 .{ }^{59}$ In the genocide chapter, he correctly sums up Hitler's intentions (although not the fact that they had been largely realized): "Some groups - such as the Jews - have to be destroyed completely." ${ }^{\prime 60}$ Lemkin's information on these facts came predominantly from publications of the Polish government-in-exile in London, especially the periodical Polish Fortnightly Review. The Civil Affairs Guides Lemkin created for the BEW feature similar information. For example, the Civil Affairs Guide on Poland from November 11, 1943, mentions the liquidation of the ghettos and claims that of 1.75 million Jews in the General Government of Poland, at most 300,000 are estimated to be alive. ${ }^{61}$

Lemkin therefore had a fairly accurate picture of Nazi policies on Jews. Unlike many contemporary commentators in America, he understood that the Nazis targeted the Jews in far more extreme ways than others (therefore he devoted a separate chapter to Jews). But he did not highlight the systematic extermination policy against the Jews. His official focus on economic and legal matters, as required by his daily work for the BEW, influenced his way of presenting the mechanics of Nazi-occupied Europe. In Axis Rule, he consistently clung to an economic and legal emphasis in elucidating Nazi policies, a tendency that obscured the focus on mass murder. The economic and legal focus of the BEW clearly colors the bulk of Axis Rule.

\section{The Emphasis on the Law}

In the third part of my argument, I would like to examine Lemkin's focus on law. ${ }^{62}$ We know that his analysis of Nazi-occupied Europe rested on a collection of legal documents from Nazi Europe. These laws and decrees were issued mostly by German military commanders, governors, and civilian administrators in the occupied territories during the first months of the occupation. Using this collection for an analysis of Nazi-occupied Europe, as Lemkin did, involves two risks.

\footnotetext{
${ }^{55}$ Raphaël Lemkin, La Réglementation des paiements internationaux. Traité de droit comparé sur les dévises, le clearing et les accords de paiements, les conflits des lois (Paris: A. Pedone, 1939); Raphaël Lemkin, Valutareglering och clearing (Stockholm: P.A. Norstedt \& Söner, 1941).

${ }^{56}$ Lemkin, Axis Rule, 50-66 and 176. See also Irvin-Erickson, Raphaël Lemkin and the Concept of Genocide, 76 and 106-108.

${ }^{57}$ Lemkin, Axis Rule, 75-76.

${ }^{58} \mathrm{Ibid} ., 22$. For background on the (false) news of killing Jews with quick-lime, conveyed by Polish resister Jan Karski, see Becker, Messagers du désastre, 85-86.

${ }^{59}$ Lemkin, Axis Rule, 75, including note 3.

${ }^{60}$ Ibid., 81.

${ }^{61}$ OSS, Research and Analysis Branch: “German Military Government Over Europe 1939-1943. Methods and Organization of Nazi Controls. General Government (Poland)," November 11, 1943, NARA, Judge Advocate General Law Library, 1944-1949, Entry 135, Box 5, 20-22. Lemkin cited the Polish Fortnightly Review in this guide, and he drew from a broad source base of German-language newspapers, including the Neue Zürcher Zeitung.

${ }^{62}$ Dan Stone has stressed Lemkin's focus on the law: Stone, Raphaël Lemkin on the Holocaust, 541.
} 
First, as every historian knows, normative texts may not be a good representation of actual practices. Although Lemkin did not write as a historian, he likely was aware of this pitfall because he had himself criticized a 1935 Nazi law on analogy - a law that stipulated that a person could be punished for an act that was not itself illegal but resembled an existing crime. ${ }^{63}$ Although Lemkin did not cite the book of German émigré Ernst Fraenkel, who defined the Nazi state as a "dual state" with a more traditional normative branch and an arbitrary prerogative branch, ${ }^{64}$ he knew that Nazi policies could go beyond stated legal practices. He devoted a special section in Axis Rule to the arbitrary terror of the SS and Gestapo in occupied countries. ${ }^{65}$

Second, the bulk of the orders come from the first two years of the war and, generally, the beginning of the occupation regimes (for example most decrees for Yugoslavia date from the first three months of the occupation, April to July $\left.1941^{66}\right)$. Although Axis Rule refers to events as late as December 1943, it contains very few orders and decrees issued later than the first trimester of 1942. These orders do not reflect the harsher practices of the later occupation years, when resistance activities and German need for manpower and raw materials had sharply increased. The survey in the magisterial Germany and the Second World War, edited by the German Military Research Institute, therefore devotes separate sections to the early and the late periods of occupation, 19391941 and 1942-1944/45, respectively. ${ }^{67}$

Lemkin's reliance on laws and decrees was likely reinforced by the difficulties he experienced in convincing his audiences and colleagues of German atrocities, as he suggests in the preface to Axis Rule.

For the outside world they [the laws and decrees] provide undeniable and objective evidence regarding the treatment of subjugated peoples of Europe by the Axis powers. The author feels that such evidence is especially necessary for the Anglo-Saxon reader, who, with his innate respect for human rights and human personality, may be inclined to believe that the Axis régime could not possibly be as cruel and ruthless as it has been hitherto described. ${ }^{68}$

In his autobiography, Lemkin reports that his American audiences, to whom he revealed some of his ideas about Nazi practices, could not believe the ruthlessness of German occupation policies. He noted the same reaction inside the BEW; his colleagues did not outright deny the atrocities but doubted that the news would be believed and taken seriously. Some colleagues dismissively pointed to World War I atrocity propaganda. Although Lemkin received an audience with Vice President Wallace and talked to him again at a dinner party, he felt that he could not dent Wallace's fundamental optimism about human nature that made it impossible for Wallace to understand Nazi cruelty. ${ }^{69}$

Through a mediator, Lemkin even contacted Eleanor Roosevelt and received permission to submit a one-page memorandum to the President, in which he allegedly highlighted Nazi atrocities and encouraged Roosevelt to issue a stern warning to Hitler and to work for the adoption

\footnotetext{
${ }^{63}$ Lemkin, Axis Rule, 27-29. Lemkin is referring to Article 2 of the Law to Change the Penal Code of 28 June 1935, in Deutsches Reichsgesetzblatt, 1935 Teil I, no. 70, 839. He had criticized the principle of analogy in previous publications, for example in works on the Soviet and the Italian (fascist) law codes: Ryszard Szawlowski, " Raphaël Lemkin (1900-1959). The Polish Lawyer Who Created the Concept of 'Genocide'," The Polish Quarterly for International Affairs, no. 2 (2005), 111. See also Herlinde Pauer-Studer, "Einleitung," in Rechtfertigungen des Unrechts. Das Rechtsdenken im Nationalsozialismus, eds. Herlinde Pauer-Studer and Julian Fink (Berlin: Suhrkamp, 2014), 91-93.

${ }^{64}$ Ernst Fraenkel, The Dual State: A Contribution to the Theory of Dictatorship (Oxford and New York: Oxford University Press, 1941).

${ }^{65}$ Lemkin, Axis Rule, 15-24, specifically 20.

${ }^{66}$ Ibid., 569-635.

${ }^{67}$ Militärgeschichtliches Forschungsamt, ed., Germany and the Second World War: Volume 5: Organization and Mobilization of the German Sphere of Power (Oxford: Clarendon Press, 2000).

${ }^{68}$ Lemkin, Axis Rule, ix.

${ }^{69}$ Wallace's diary reveals that he was meeting with many people working for the BEW in late 1942: Wallace, Price of Vision, diary entries of November 27 and December 3, 1942, 138 and 141. Lemkin, Totally Unofficial, 113-115. See also Sands, East West Street, 177-179.
} 
of an international law against occupation crimes. But Lemkin claims to have received only a noncommittal response, stating that Roosevelt was aware of the problems and that a warning would be forthcoming at the right time. In his autobiography, Lemkin points out that he therefore decided to bring the information he had to the American people by using his collection of Nazi laws and decrees for the occupied territories as incontrovertible evidence. ${ }^{70}$

Aside from proving genocidal occupation practices, Lemkin's focus on the law also served his aim to improve international law. Axis Rule documents many violations of the Hague Regulations by Germany, and one of the two major proposals Lemkin made in the book is the creation of an international oversight mechanism similar to the Geneva Convention on Prisoners of War (1929). ${ }^{71}$ In analogy to the delegations from neutral countries visiting POW camps, Lemkin wanted neutral delegations to visit occupied areas and ensure a legal and humane treatment of their civilian populations. This proposal may sound promising, but Lemkin falsely implied that the POW regime in World War II was following international law - the Geneva Convention and, for those countries who had not ratified it, the Hague Regulations of 1907. He was oblivious to the atrocious treatment of Soviet POWs by Nazi Germany and never mentioned the harsh and illegal treatment of Polish POWs, which occurred despite the fact that Poland, unlike the Soviet Union, had ratified the Geneva Convention. While the Geneva Convention remained the basis for the German treatment of western POWs, Lemkin did not consider the many ways in which Nazi authorities stretched and abused some of its provisions. ${ }^{72}$

The demand for tighter legal provisions regarding occupations was related to Lemkin's desire to see adoption of an international law against genocide in war and peace. ${ }^{73}$ He repeatedly pointed out that he had made a similar proposal without using the term genocide at the Fifth International Conference for the Unification of Penal Law in Madrid in October 1933. He had drafted a special report proposing the codification of two new crimes that he called "vandalism" and "barbarity" (originally in this order). Vandalism denoted the destruction of artworks and cultural institutions in peace and in war, and barbarity meant acts of aggression against a defenseless population, including massacres and pogroms, but also acts of humiliation and discrimination. ${ }^{74}$ Lemkin's proposals included a clause on universal jurisdiction, the notion that perpetrators of these new crimes could be tried anywhere in the world and not just in the country where they had committed them, and he reminded readers in Axis Rule that the prosecution of Nazi war criminals would be much easier had his suggestions been adopted before the war. ${ }^{75}$

In a speech to the North Carolina Bar Association in May 1942, Lemkin even claimed that adoption of his Madrid proposals would have helped to prevent the war. He told his audience that he had read his proposals in Madrid and that the German delegation had left the room in protest. ${ }^{76}$ The minutes of the conference, however, do not list Lemkin, nor do they list a German delegation. In his autobiography, Lemkin admitted that he had not attended the conference, allegedly because he had received a phone call from the chairman of the Polish delegation who told him that the

\footnotetext{
${ }^{70}$ Lemkin, Totally Unofficial, 115-116. I searched extensively in the FDR Library but could not find Lemkin's memo. A later letter from Lemkin to Eleanor Roosevelt reveals that the mediator was Betty Hight, a friend of Eleanor Roosevelt who also worked for the BEW. Betty Hight seems to have communicated Roosevelt's answer orally: Raphäel Lemkin, "Letter to Eleanor Roosevelt," February 1, 1950, Raphaël Lemkin Papers, P-154, AJHS, Box 2, Folder 3. Betty Hight, as the letters to her family reveal, was a frequent dinner guest in the White House during the war, and the memo may have been discussed informally on one of these occasions. Betty Hight Papers, FDR Presidential Library.

${ }^{71}$ Lemkin, Axis Rule, 94-95.

${ }^{72}$ Rüdiger Overmans, "Die Kriegsgefangenenpolitik des Deutschen Reiches 1939 bis 1945," in Das Deutsche Reich und der Zweite Weltkrieg, ed. Jörg Echternkamp (Munich: Deutsche Verlags-Anstalt, 2005).

${ }^{73}$ Lemkin, Axis Rule, 90-94.

${ }^{74}$ Raphaël Lemkin, "Rapport et projet de textes présentés par M. Raphaël Lemkin," in Ve Conférence internationale pour l'unification du droit pénal: Actes de la conférence, ed. Manuel Lopez-Rey Arrojo (Paris: Pedone, 1935). He also presented his ideas in an article for an Austrian law journal (in German) and in a stand-alone booklet (in French), published in Paris in 1935. These three texts are quite different: Raphaël Lemkin, Les actes constituant un danger général (interétatique) considérés comme délits de droits des gens (Paris: Pedone, 1935); Raphaël Lemkin, "Akte der Barbarei und des Vandalismus als delicta juris gentium," Internationales Anwaltsblatt 19, no. 6 (1933).

${ }^{75}$ Lemkin, Axis Rule, 91-92. Lemkin here speaks of "universal repression," not universal jurisdiction.

${ }^{76}$ Lemkin, Law and Lawyers in the European Subjugated Countries, 112.
} 
Minister of Justice opposed Lemkin's presence in Madrid. Lemkin hinted that an anti-Semitic paper had attacked his proposal as a selfish defense of the Jewish race and not as an initiative in the interest of the Polish state. Polish historian Ryszard Szawlowski casts doubt on this explanation and claims that there is no evidence for it in the archives of the Polish Foreign Ministry. ${ }^{77}$ In any case, Lemkin kept attending international law conferences after Madrid, although usually not as a member of the Polish delegation. For example, he presented a report on terrorism in Copenhagen in 1935 and a paper on the role of law in the protection of international peace in Paris in 1937, neither of which mentioned vandalism and barbarity. ${ }^{78}$ Lemkin's idea to define vandalism and barbarity as new international crimes did not garner much attention at the time, and his thinking was still in flux. The breadth of policies that he defined as genocidal in Axis Rule indicates that genocide is more than just an amalgam of vandalism and barbarity. ${ }^{79}$ It is a matter of dispute whether Lemkin hoped that Axis Rule and an international law against genocide, adopted already during the war, would help to stop Nazi atrocities (my sense is that Lemkin may have shared this hope at some time but that it was not relevant any more when he finished the manuscript) ${ }^{80} \mathrm{But}$ he certainly put high hopes in a postwar international treaty reviving his 1933 proposal, and Axis Rule was meant to be a legal resource informing negotiations to that end.

\section{Conclusion}

The breadth and complexity of Lemkin's definition of "genocide" results from several influences during the time he developed the concept. One of them is a belief that Nazi Germany was engineering a demographic revolution that would leave Germany predominant in Europe regardless of the outcome of the military conflict. This notion facilitated the assumption of a coherent cynical motivation behind disparate policies, laws, and decrees. It ascribed a primarily demographic motivation to the exploitation of foreign labor, for example, while downplaying the need for labor in order to win the war. This notion also assumed that the cultural policies and population exchanges initiated by the Nazi regime would somehow survive the end of the war even if Germany lost and that the defeat of Nazi Germany would occur relatively smoothly and with little bloodshed for Germany. Second, Lemkin's daily work at the BEW reinforced his focus on economic and legal matters and helps to explain why they occupy such a prominent place in Axis Rule. His job provided Lemkin with good access to information and encouraged a detailed analysis of Nazi occupation techniques, but it prioritized economic exploitation over atrocities, with a view to restitution after the liberation of the occupied territories. Third, Lemkin's focus on the law and his belief in its curative effect, although already evident before the war, was reinforced by his

${ }^{77}$ Lemkin, Totally Unofficial, 23. According to the minutes of the conference, the chairman of the Polish delegation was E.S. Rappaport, who had accompanied Lemkin to other international conferences. Szawlowski criticizes the representations of this story in the works of many western authors, defending the Polish government against anti-Semitic tendencies. He reveals that the anti-Semitic article appeared after the conference (and can therefore not have been a motive for preventing Lemkin's attendance). Szawlowski, Lemkin's Life Journey, 35. James Loeffler has demonstrated that Lemkin was an active and outspoken Zionist in the 1920s. Loeffler points out that Lemkin experienced an "immediate anti-Semitic backlash" to his ideas in Warsaw: James Loeffler, "Becoming Cleopatra: The Forgotten Zionism of Raphaël Lemkin," Journal of Genocide Research 19, no. 3 (2017), 340-60 (here 349).

${ }^{78}$ Raphaël Lemkin, La Protection de la paix par le droit pénal. Rapport présenté au IVe Congrès international de Droit pénal (Paris, July 26-31, 1937) (Paris: Marchal et Billard, 1938). In his report for the Madrid conference (in the original version), Lemkin had discussed terrorism at length but concluded that it normally is already covered by national laws and does not make much sense as a crime causing international harm. His report at the Copenhagen conference disagrees. Raphaël Lemkin, "Terrorisme, rapport," in Vlème Conférence internationale pour l'unification du droit pénal (Copenhagen, 1935), ed. August Goll, et al. (Paris: Pedone, 1938).

${ }^{79}$ It is a matter of debate whether genocide represents a radically new concept. Lemkin said in Axis Rule: "New conceptions require new terms." (79). Yet, he also argued that genocide was an amalgam of barbarity and vandalism (91). For more specific information on this debate, see Irvin-Erickson, Lemkin, 82-84, and Anson Rabinbach, "The Challenge of the Unprecedented- Raphaël Lemkin and the Concept of Genocide," Simon Dubnow Institute Yearbook 4 (2005).

${ }^{80}$ See Irvin-Erickson, Lemkin, who argues for this notion, whereas Korey argues against it in Korey, Short Titles, 17. In Totally Unofficial, Lemkin claimed that he hoped that an international treaty might still save at least "a part of the people," but the date of this reflection is unclear, Raphaël Lemkin, Totally Unofficial: The Autobiography of Raphäl Lemkin, edited by Donna-Lee Frieze (New Haven and London: Yale University Press, 2013), 114. It likely was late 1942 - following Lemkin's meetings with Wallace. 
desire to prove German violations to a hesitant American public and by his hope to contribute to a legal condemnation of genocide in all of its forms after the war. This focus favored Nazi violations of international law that could be proven through legal texts and therefore encouraged a broad definition of genocidal acts while obscuring the most heinous crimes.

\section{Acknowledgements}

I thank Hilary Earl, Doris Bergen, Douglas Irvin-Erickson, Benjamin Lieberman, and the journal's two anonymous reviewers for comments and constructive criticism of an earlier version of this article. I also thank my son Anselm Scheck for helping me search for Lemkin's memo to President Roosevelt. I am especially grateful for the Audrey Wade Hittinger Katz and Sheldon Toby Katz endowed chair, which allowed me to do the archival research for this project.

\section{Bibliography}

Acheson, Dean. Present at the Creation. My Years in the State Department. New York: Norton, 1969.

"Allen R. Rosenberg to Division and Section Heads." September 2, 1944. National Archives and Records Administration, RG 169, Foreign Economic Administration, Washington, DC, United States. Entry 216, Box 1137.

Becker, Annette. Messagers du désastre: Raphaël Lemkin, Jan Karski et les génocides. Paris: Fayard, 2018. Bessel, Richard. Germany 1945: From War to Peace. New York: Harper Collins, 2009.

Betty Hight Papers. FDR Presidential Library, Hyde Park, NY, United States.

Breitman, Richard, Norman Goda, Timothy Naftali, and Robert Wolfe. U.S. Intelligence and the Nazis. New York: Cambridge University Press, 2005. https://doi.org/10.3138/cjh.41.1.163

Butcher, Thomas M. "A 'Synchronized Attack': On Raphaël Lemkin's Holistic Conception of Genocide." Journal of Genocide Research 15, no. 3 (2013), 253-271.

https://doi.org/10.1080/14623528.2013.821221

Cooper, John. Raphaël Lemkin and the Struggle for the Genocide Convention. Basingstoke and New York: Palgrave Macmillan, 2015 [first 2008].

"Death under the New Order." New York Times (1923-Current file), March 10,1942.

Derks, Scott. The Value of A Dollar: Prices and Incomes in the United States from 1860 to 2009. Armenia: Grey House Publishers, 2009.

Douglas, Ray M. Orderly and Humane: The Expulsion of the Germans after the Second World War. New Haven: Yale University Press, 2012.

Elder, Tanya. “What You See Before Your Eyes: Documenting Raphaël Lemkin's Life by Exploring His Archival Papers, 1900-1959." In The Origins of Genocide: Raphaël Lemkin as a Historian of Mass Violence, edited by Dominik J. Schaller and Jürgen Zimmerer, 25-55. London and New York: Routledge, 2009. https://doi.org/10.1080/14623520500349910

Ernst, Daniel R. "The Ideal and the Actual in the State: William Hurst at the Board of Economic Warfare." In Total War and the Law: The American Home Front in World War II, edited by Daniel R. Ernst and Victor Jew, 149-183. Westport: Praeger, 2002.

Foreign Economic Administration. Report to Congress on Operations of the Foreign Economic Administration. September 25, 1944. Washington, DC: United States Government Printing Office, 1944.

Fraenkel, Ernst. The Dual State: A Contribution to the Theory of Dictatorship. Oxford and New York: Oxford University Press, 1941.

Fritz, Stephen. Endkampf: Soldiers, Civilians, and the Death of the Third Reich. Lexington: University Press of Kentucky, 2004. https://doi.org/10.1086/ahr/110.2.570

Fritzsche, Peter. An Iron Wind: Europe under Hitler. New York: Basic Books, 2016.

Helton, H. Stephen. Preliminary Inventory of the Records of the Foreign Economic Administration. Washington, DC: The National Archives, 1951.

"Investigation A." November 17, 1942. Raphaël Lemkin, personnel files, Board of Economic Warfare, National Personnel Records Center, Saint Louis, Missouri, United States.

Irvin-Erickson, Douglas. Raphaël Lemkin and the Concept of Genocide. Philadelphia: University of Pennsylvania Press, 2017. https://doi.org/10.1007/s12142-017-0475-1 
Kershaw, Ian. The Nazi Dictatorship: Problems and Perspectives of Interpretation, 5th ed. London: Bloomsbury, 2015.

Koistinen, Paul A.C. Arsenal of World War II: The Political Economy of American Warfare, 1940-1945, Modern War Studies. Lawrence: University Press of Kansas, 2004.

Korey, William. An Epitaph for Raphaël Lemkin. New York: Jacob Blaustein Institute for the Advancement Human Rights of the American Jewish Committee, 2001.

Leff, Laurel. Buried by the Times: The Holocaust and America's Most Important Newspaper. New York: Cambridge University Press, 2005.

Lemkin, Raphaël. "Akte der Barbarei und des Vandalismus als delicta juris gentium." Internationales Anwaltsblatt 19, no. 6 (1933), 117-119.

. "Autobiography Draft." n.d. Manuscripts and Archives Division, New York Public Library, New York City, United States. Microfilm, Reel 2, Notebooks, 24a and 25.

Axis Rule in Occupied Europe. Laws of Occupation, Analysis of Government, Proposals for Redress. Washington, DC: Carnegie Endowment for International Peace, 1944.

"Civil Affairs Guides." On the Nazi party, the courts, the police, and the SS. National Archives and Records Administration, RG 153 Judge Advocate General, Office of Economic Warfare, Washington, DC, United States of America. National Archives and Records Administration, Washington, DC, United States of America. Boxes 2 and 5, L-99.

. "Dr. Raphaël Lemkin's Material." Office of the Judge Advocate General (Navy), RG 125, General Records, 1945-1949, Washington, DC, United States. Entry A1-13. NAID 16465283. . "Genocide. A New International Crime. Punishment and Prevention." Revue internationale de droit pénal. Paris, 1946. 360-370. Raphaël Lemkin Papers, P-154, American Jewish Historical Society, New York City, United States. Box 13, Folder 2.

. "German Military Government Over Europe 1939-1943 Methods and Organization of Nazi Controls. German Military and Police Tribunals in Occupied Territories." October 25, 1943. National Archives and Records Administration, Judge Advocate General Law Library, 1944-1949, Washington, DC, United States. Entry 135, Box 5.

--------. La Protection de la paix par le droit pénal. Rapport présenté au IVe Congrès international de Droit pénal (Paris, July 26-31, 1937). Paris: Marchal et Billard, 1938.

--------. La Réglementation des paiements internationaux. Traité de droit comparé sur les dévises, le clearing et les accords de paiements, les conflits des lois. Paris: A. Pedone, 1939.

--------. "Law and Lawyers in the European Subjugated Countries." In Proceedings of the FortyFourth Annual Session of the North Carolina Bar Association, edited by Allston Stubbs, 107-16. Durham: Christian Printing, 1942.

---------. Les actes constituant un danger général (interétatique) considérés comme délits de droits des gens. Paris: Pedone, 1935.

---------. “Letter to Eleanor Roosevelt." February 1, 1950. Raphaël Lemkin Papers, P-154, American Jewish Historical Society, New York City, NY, United States. Box 2, Folder 3.

. "Military Government in Europe." Chapel Hill: University of North Carolina Law Library, 1942.

"Rapport et projet de textes présentés par M. Raphaël Lemkin." In Ve Conférence internationale pour l'unification du droit pénal: Actes de la conférence, edited by Manuel LopezRey Arrojo, 48-56. Paris: Pedone, 1935.

. "Terrorisme, rapport." In VIème Conférence Internationale pour l'unification du droit péna (Copenhagen 1935), edited by August Goll, Vespasien Pella, Charles Bonca Ingwersen and Henrik Emil Sachs. Paris: Pedone, 1938.

"The Crime of Genocide." In Bulletin de la Commission internationale et pénitentiaire, vol. XII, 34-43. n.d. Raphaël Lemkin Papers, P-154, American Jewish Historical Society, New York City, United States. Box 5, Folder 3.

--------. Totally Unofficial: The Autobiography of Raphaël Lemkin. Edited by Donna-Lee Frieze. New Haven and London: Yale University Press, 2013.

--------. Valutareglering och clearing: Bearbetat efter Författarens Föreläsningar vid Stockholms Högskola Hösten 1940. Stockholm: P.A. Norstedt \& Söner, 1941. 
Loeffler, James. "Becoming Cleopatra: The Forgotten Zionism of Raphaël Lemkin." Journal of Genocide Research 19, no. 3 (2017), 340-60. https://doi.org/10.1080/14623528.2017.1349645

Lowe, Keith. Savage Continent: Europe in the Aftermath of World War II. New York: St. Martin's, 2012. Mazower, Mark. Hitler's Empire: How the Nazis Ruled Europe. New York: Penguin, 2008.

-------. No Enchanted Palace: The End of Empire and the Ideological Origins of the United Nations. Princeton: Princeton University Press, 2009.

Meierhenrich, Jens. "Introduction: The Study and History of Genocide." In Genocide: A Reader, edited by Jens Meierhenrich, 3-55. Oxford and New York: Oxford University Press, 2014.

Militärgeschichtliches Forschungsamt, ed. Germany and the Second World War: Volume 5: Organization and Mobilization of the German Sphere of Power. Oxford: Clarendon Press, 2000.

Moses, A. Dirk. "Raphaël Lemkin, Culture, and the Concept of Genocide." In The Oxford Handbook of Genocide Studies, edited by Donald Bloxham and A. Dirk Moses, 19-41. Oxford: Oxford University Press, 2010.

Office of Strategic Services, Research and Analysis Branch. "German Military Government Over Europe 1939-1943. Methods and Organization of Nazi Controls. General Government (Poland)." November 11, 1943. National Archives and Records Administration, Judge Advocate General Law Library, 1944-1949, Washington, DC, United States. Entry 135, Box 5.

Overmans, Rüdiger. Deutsche militärische Verluste im Zweiten Weltkrieg, Beiträge zur Militärgeschichte. Munich: Oldenbourg, 1999. https://doi.org/10.1524/9783486594140

. "Die Kriegsgefangenenpolitik des Deutschen Reiches 1939 bis 1945." In Das Deutsche Reich und der Zweite Weltkrieg, edited by Jörg Echternkamp, 729-875. Munich: Deutsche VerlagsAnstalt, 2005.

Pauer-Studer, Herlinde. "Einleitung." In Rechtfertigungen des Unrechts. Das Rechtsdenken im Nationalsozialismus, edited by Herlinde Pauer-Studer and Julian Fink, 15-135. Berlin: Suhrkamp, 2014.

Powers, Samantha. "Introduction to the First Edition." In Axis Rule in Occupied Europe. Laws of Occupation, Analysis of Government, Proposals for Redress, by Raphaël Lemkin, xvii-xxiii. Clark, NJ: The Lawbook Exchange Ltd., 2014.

Rabinbach, Anson. "The Challenge of the Unprecedented - Raphaël Lemkin and the Concept of Genocide." Simon Dubnow Institute Yearbook 4 (2005), 397-420.

Rauschning, Hermann. The Revolution of Nihilism. Warning to the West. Translated by E.W. Dickes. New York: Alliance Book Corporation, 1939.

. The Voice of Destruction. New York: Putnam, 1940.

"Recommendation to the Personnel Officer." December 9, 1942. Raphaël Lemkin, personnel files, Board of Economic Warfare, National Personnel Records Center, Saint Louis, MO, United States.

Reoccupation Division. “Guide Books.” National Archives and Records Administration, RG 169, Foreign Economic Administration, Washington, DC, United States. Entry 216, Box 1137.

"Request for Occupational Deferment." Late 1942/ early 1943. Raphaël Lemkin, personnel files, Board of Economic Warfare, National Personnel Records Center, Saint Louis, MO, United States.

"Request for Occupational Deferment." n.d. Raphaël Lemkin, personnel files of the Board of Economic Warfare, National Archives and Records Administration, Washington, DC, United States.

Sands, Philippe. East West Street: On the Origins of "Genocide" and "Crimes Against Humanity". New York: Alfred A. Knopf, 2016.

Schabas, William. Genocide in International Law: The Crime of Crimes. Cambridge, UK and New York: Cambridge University Press, 2000.

-------. "Introduction to the Second Edition by The Lawbook Exchange, Ltd." In Axis Rule in Occupied Europe. Laws of Occupation, Analysis of Government, Proposals for Redress, by Raphaël Lemkin, vii-xvi. Clark, NJ: The Lawbook Exchange Ltd., 2014.

Schlesinger, Arthur M. Jr. A Life in the Twentieth Century. Innocent Beginnings, 1917-1950. Boston and New York: Houghton Mifflin, 2000. 
Stevens, Donald G. "Organizing for Economic Defense: Henry Wallace and the Board of Economic Warfare's Policy Initiatives, 1942." Presidential Studies Quarterly 26, no. 4 (1996), 1126-1139.

Stone, Dan. "Raphaël Lemkin on the Holocaust." Journal of Genocide Research 7, no. 4 (2005): 539-550. https://doi.org/10.1080/14623520500349985

. "Raphaël Lemkin on the Holocaust." In The Origins of Genocide: Raphaël Lemkin as a Historian of Mass Violence, edited by Dominik J. Schaller and Jürgen Zimmerer, 95-106. London and New York: Routledge, 2009.

Stubbs, Allston, ed. Proceedings of the Forty-Fourth Annual Session of the North Carolina Bar Association. Durham: Christian Printing, 1942.

Szawlowski, Richard. “Raphaël Lemkin's Life Journey: From Creative Legal Scholar and Well-to-do Lawyer in Warsaw until 1939 to Pinnacle of International Achievements during the 1940s in the United States, Ending Penniless Crusader in New York in the 1950s." In Rafal Lemkin: A Hero of Humankind, edited by Bienczyl-Missala. Agnieszka and Slawomir Debski, 31-57. Warsaw: The Polish Institute of International Affairs, 2010.

Szawlowski, Ryszard. "Raphaël Lemkin (1900-1959). The Polish Lawyer Who Created the Concept of 'Genocide'." The Polish Quarterly for International Affairs no. 2 (2005), 99-134.

Wallace, Henry A. The Price of Vision: The Diary of Henry A. Wallace. Boston: Houghton Mifflin, 1973.

Weiss-Wendt, Anton. The Soviet Union and the Gutting of the UN Genocide Convention. Critical Human Rights. Madison and London: University of Wisconsin Press, 2017.

Weitz, Eric D. A Century of Genocide: Utopias of Race and Nation. Princeton and Oxford: Princeton University Press, 2003. 